\title{
Emticicia ginsengisoli sp. nov., a species of the family 'Flexibacteraceae' isolated from soil of a ginseng field
}

\author{
Correspondence \\ Wan-Taek Im \\ wandra@kaist.ac.kr \\ Feng-Xie Jin \\ fxjin@dlpu.edu.cn
}

\author{
Qing-Mei Liu, ${ }^{1}$ Leonid N. Ten, ${ }^{2}$ Hong-Shan Yu, ${ }^{3}$ Feng-Xie Jin, ${ }^{3}$ \\ Wan-Taek $\operatorname{Im}^{1}$ and Sung-Taik Lee ${ }^{1}$ \\ ${ }^{1}$ Department of Biological Sciences, Korea Advanced Institute of Science and Technology, \\ 373-1 Guseong-dong, Yuseong-gu, Daejeon 305-701, Republic of Korea \\ ${ }^{2}$ Department of Biology and Medicinal Science, Pai Chai University, 14 Yonja-1st Street, \\ Seo-Gu, Daejeon 302-735, Republic of Korea \\ ${ }^{3}$ College of Bio and Food Technology, Dalian Polytechnic University, Qinggong-yuan No. 1, \\ Ganjingzi-qu, Dalian 116034, PR China
}

The Cytophaga-Flavobacterium-Bacteroidetes group, which is also known as the phylum Bacteroidetes (Ludwig \& Klenk, 2001), is considered to comprise organisms associated with the degradation of organic compounds such as complex polysaccharides (Höfle, 1982; Pinhassi et al., 1999). This group of organisms is an important component of marine microbial communities (Glöckner et al., 1999). In recent years, there has been a surge in the number of publications describing novel genera within the phylum Bacteroidetes, mainly concerning organisms within the family Flavobacteriaceae, including Aquimarina (Nedashkovskaya et al., 2005), Epilithonimonas (O'Sullivan et al., 2006), Formosa (Ivanova et al., 2004), Gillisia (Van Trappen et al., 2004), Kordia (Sohn et al., 2004), Persicivirga (O'Sullivan et al., 2006) and Ulvibacter (Nedashkovskaya et al., 2004). Recently, some novel genera outside the family Flavobacteriaceae, including Adhaeribacter (Rickard et al., 2005), Hongiella (Yi \& Chun, 2004), Arcicella (Nikitin et al., 2004) and Belliella (Brettar et al., 2004), have also been described. In addition, a novel family within the phylum

The GenBank/EMBL/DDBJ accession number for the 16S rRNA gene sequence of strain Gsoil $085^{\top}$ is $A B 245370$.
Bacteroidetes was recently described: the family Cryomorphaceae contains five new genera, Brumimicrobium, Cryomorpha, Crocinitomix, Owenweeksia and Fluviicola (Bowman et al., 2003; Lau et al., 2005; O'Sullivan et al., 2005). Most of these newly described bacteria were isolated from marine environments and hypersaline lakes, but a few bacterial strains were isolated from other habitats, such as soil (Reichenbach, 1989).

The genus Emticicia was recently described by Saha \& Chakrabarti (2006) and currently comprises only one species, Emticicia oligotrophica. It was isolated on nutritionally poor medium from warm spring water. It was characterized as a Gram-negative, strictly aerobic, chemoorganotrophic bacterium comprising non-motile, rod- or coccus-shaped cells. The major fatty acid was iso- $\mathrm{C}_{15: 0}$, which is also present in many members of the family 'Flexibacteraceae'. On the basis of the 16S rRNA gene sequence, the genus Emticicia is affiliated to the family 'Flexibacteraceae' in the phylum Bacteroidetes.

During the course of a study on the culturable aerobic and facultatively anaerobic bacterial community in soil from a ginseng field in Pocheon Province, South Korea, a large 
number of bacteria were isolated (Im et al., 2005). One of these isolates, strain Gsoil $085^{\mathrm{T}}$, was identified as belonging to the family 'Flexibacteraceae' within the phylum Bacteroidetes and was the subject of further taxonomic investigation in order to establish its phylogenetic affiliation. Here we report on its taxonomic position, including its genotypic, chemotaxonomic and classical phenotypic characteristics, and propose that strain Gsoil $085^{\mathrm{T}}$ represents a novel species of the genus Emticicia.

Strain Gsoil $085^{\mathrm{T}}$ was originally isolated from soil from a ginseng field in Pocheon Province, South Korea, as described by Liu et al. (2006), using modified R2A agar plates incubated under aerobic conditions. The strain was routinely cultured on $\mathrm{R} 2 \mathrm{~A}$ agar at $30{ }^{\circ} \mathrm{C}$ and maintained as a glycerol suspension $\left(20 \%\right.$, w/v) at $-70{ }^{\circ} \mathrm{C}$.

For the phylogenetic analysis of strain Gsoil $085^{\mathrm{T}}$, DNA was extracted using a genomic DNA extraction kit (Core Biosystem), the 16S rRNA gene was amplified with a PCR and sequencing of the purified PCR product was carried out according to Kim et al. (2005). The almost-complete $16 \mathrm{~S}$ rRNA gene sequence was compiled using SeqMan software (DNASTAR). The 16S rRNA gene sequences of related taxa were obtained from the GenBank database and multiple alignments were created using the CLUSTAL_X program (Thompson et al., 1997). Gaps were edited in the BioEdit program (Hall, 1999). Evolutionary distances were calculated using Kimura's two-parameter model (Kimura, 1983). Phylogenetic trees were constructed with the neighbour-joining method (Saitou \& Nei, 1987) using the MEGA3 program (Kumar et al., 2004) with bootstrap values based on 1000 replications (Felsenstein, 1985).

The length of the almost-complete $16 \mathrm{~S}$ rRNA gene sequence of strain Gsoil $085^{\mathrm{T}}$ was 1463 bp (base position 9-1505 with respect to the Escherichia coli numbering system). Preliminary sequence comparisons against the $16 \mathrm{~S}$ rRNA gene sequences deposited in GenBank indicated that the isolate belonged to the family 'Flexibacteraceae' within the phylum Bacteroidetes. On the basis of 16S rRNA gene similarities, the closest cultured relative of strain Gsoil $085^{\mathrm{T}}$ was E. oligotrophica GPTSA100-15 ${ }^{\mathrm{T}}(94.6 \%)$. Lower sequence similarities $(<83.0 \%)$ were found with respect to other member species of the family. This relationship between our isolate and other members of the family 'Flexibacteraceae' was also evident in the phylogenetic tree (Fig. 1). DNA-DNA hybridization between strain Gsoil $085^{\mathrm{T}}$ and its nearest phylogenetic neighbours was not attempted since strains differing by $>3.0 \%$ at the $16 \mathrm{~S}$ rRNA gene level are unlikely to exhibit $>70 \%$ relatedness at the whole-genome level (Stackebrandt \& Goebel, 1994).

A Gram reaction was performed using the non-staining method, as described by Buck (1982). Cell morphology was observed under a Nikon light microscope at $\times 1000$ magnification, using cells grown for 3 days at $25^{\circ} \mathrm{C}$ on R2A agar. Catalase and oxidase tests were performed as outlined by Cappuccino \& Sherman (2002). The defined agar medium (containing basal salt media) used for singlecarbon-source assimilation studies contained the following $\left(\mathrm{g} \mathrm{l}^{-1}\right): \mathrm{K}_{2} \mathrm{HPO}_{4}, 1.8 \mathrm{~g} ; \mathrm{KH}_{2} \mathrm{PO}_{4}, 1.08 \mathrm{~g} ; \mathrm{NaNO}_{3}, 0.5 \mathrm{~g}$;

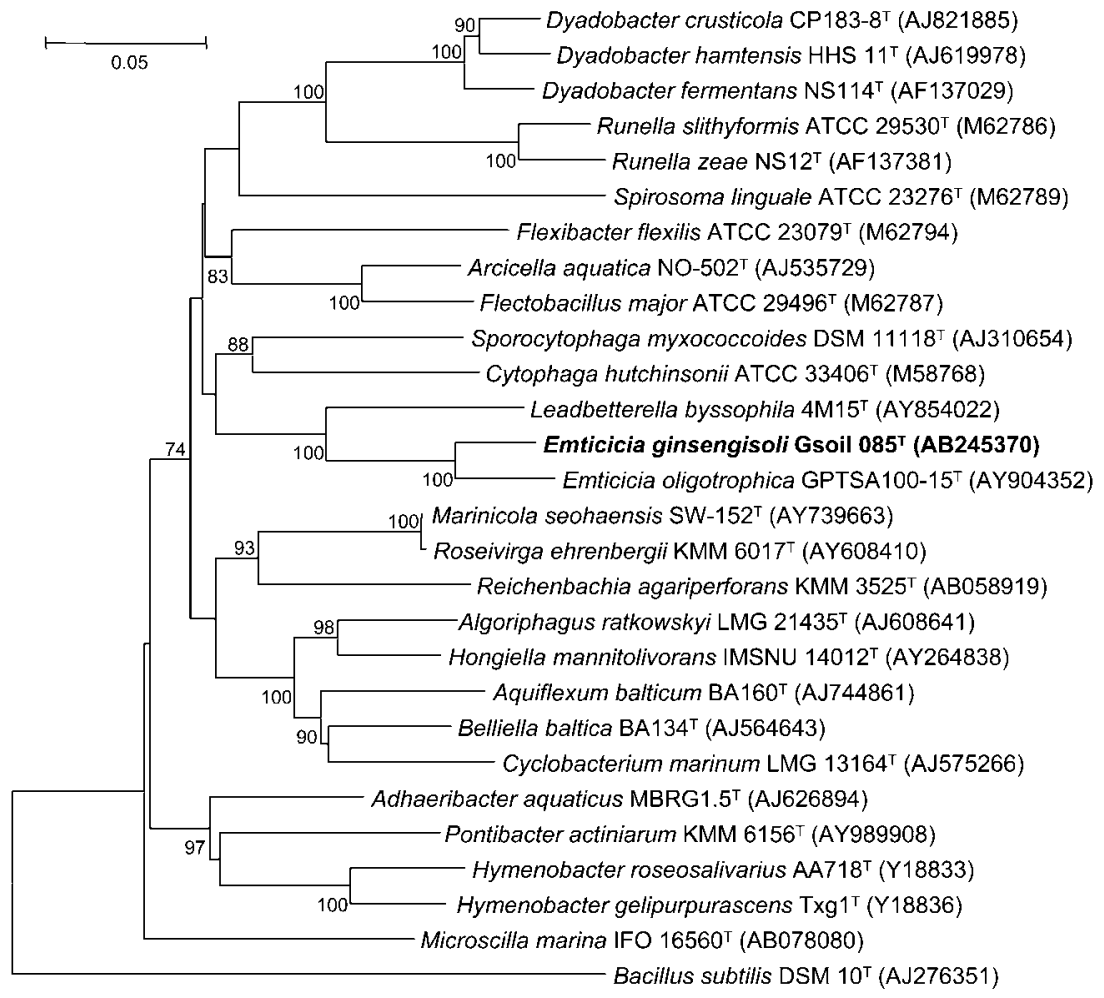

Fig. 1. Neighbour-joining phylogenetic tree, based on 16S rRNA gene sequences, showing the positions of strain Gsoil $085^{\top}$ and its nearest neighbours. Bootstrap percentages (based on 1000 replications) $>70 \%$ are shown at branch points. Bar, 5 substitutions per 100 nucleotide positions. 
Table 1. Differential characteristics of strain Gsoil $085^{\top}$ and the nearest relative, E. oligotrophica MTCC6937 $^{\top}$

Data for E. oligotrophica MTCC6937 ${ }^{\mathrm{T}}$ were taken from Saha \& Chakrabarti (2006). Both strains were Gramnegative aerobes consisting of non-spore-forming, non-motile, rod-shaped cells. Both strains showed $\mathrm{NaCl}$ tolerance of $<1 \%(\mathrm{w} / \mathrm{v})$ and were positive for the following: nitrate reduction to nitrite; production of catalase and oxidase; growth on R2A, 1/100 LB agar, 1/100 NA, 1/100 TSA, 1/100 MacConkey agar, R3A, 1/100 TSIA and 1/100 MHA; assimilation of raffinose; sensitivity to chloramphenicol, erythromycin, neomycin, novobiocin, streptomycin and tetracycline. Both strains were negative for the following: $\beta$-galactosidase activity; degradation of xylan, cellulose and chitin; acid production from mannitol, sorbitol, amygdalin and arabinose; assimilation of D-fucose, ethanol, D-adonitol, dulcitol, D-mannitol, D-sorbitol and xylitol; growth on LB agar, MacConkey agar and TSIA. +, Positive; W, weakly positive; -, negative; R, resistant; s, sensitive; NA, data not available from the sources used.

\begin{tabular}{|lcc|}
\hline Characteristic & Gsoil $\mathbf{~ 0 8 5}^{\mathbf{T}}$ & E. oligotrophica MTCC6937 $^{\mathbf{T}}$ \\
\hline Colony colour & Orange & Light pink \\
Urease activity & - & + \\
Temperature range for growth $\left({ }^{\circ} \mathrm{C}\right)$ & $4-30$ & $15-42$ \\
pH range for growth & $5.0-8.5$ & $5.0-11.0$ \\
Response to antibiotics & & \\
Ampicillin $(10 \mu \mathrm{g})$ & $\mathrm{R}$ & $\mathrm{S}$ \\
Gentamicin $(10 \mu \mathrm{g})$ & $\mathrm{R}$ & $\mathrm{S}$ \\
Kanamycin $(30 \mu \mathrm{g})$ & $\mathrm{R}$ & $\mathrm{S}$ \\
Lincomycin $(2 \mu \mathrm{g})$ & $\mathrm{R}$ & $\mathrm{S}$ \\
Penicillin G $(10 \mathrm{U})$ & $\mathrm{R}$ & $\mathrm{S}$ \\
Cephalothin $(20 \mu \mathrm{g})$ & $\mathrm{R}$ & $\mathrm{NA}$ \\
Carbenicillin $(6 \mu \mathrm{g})$ & $\mathrm{R}$ & $\mathrm{NA}$ \\
Utilization as sole carbon sources & & $\mathrm{W}$ \\
D-Galactose & - & $\mathrm{W}$ \\
D-Glucose & - & + \\
Starch & - & $\mathrm{W}$ \\
D-Fructose & - & $\mathrm{W}$ \\
D-Arabinose & - & $\mathrm{W}$ \\
L-Arabinose & - & + \\
Cellobiose & - & $\mathrm{W}$ \\
Sucrose & + & + \\
Amygdalin & - & $\mathrm{W}$ \\
Glycerol & - & + \\
Acid production from glucose, sucrose and melibiose & - & \\
Growth on NA, TSA and MHA & + & \\
DNA G+C content $(\mathrm{mol} \%)$ & 40.5 & \\
& & \\
& & \\
\hline
\end{tabular}

$\mathrm{NH}_{4} \mathrm{Cl}, 0.5$ g; KCl, 0.1 g; $\mathrm{MgSO}_{4}, 0.1$ g; $\mathrm{CaCl}_{2}, 0.05$ g. A vitamin solution (Widdel \& Bak, 1992), a trace element solution (SL-10; Widdel et al., 1983) and a selenite/ tungstate solution (Tschech \& Pfennig, 1984) were added to the medium, and the $\mathrm{pH}$ was adjusted to 6.8 . Filtersterilized carbon sources (each at $0.1 \%, \mathrm{w} / \mathrm{v}$ ) were added to this medium. Plates were incubated for 7 days at $25{ }^{\circ} \mathrm{C}$ and inspected visually. Negative control media did not contain any added carbon source. A positive control culture was grown on R2A medium. Some physiological characteristics were determined with API 20E galleries according to the instructions of the manufacturer (bioMérieux). Anaerobic growth was performed in serum bottles by adding thioglycolate $\left(1 \mathrm{~g} \mathrm{l}^{-1}\right)$ to $\mathrm{R} 2 \mathrm{~A}$ broth and replacing the upper air layer with nitrogen gas. Nitrate- and nitrite-reduction tests were performed in serum bottles containing R2A broth supplemented with $\mathrm{KNO}_{3}(10 \mathrm{mM})$ or $\mathrm{NaNO}_{2}$ (10 mM), respectively. Tests for the degradation of DNA [by flooding DNase agar (Scharlau) plates with $1 \mathrm{M} \mathrm{HCl}$, casein, chitin, starch (Atlas, 1993), lipid (Kouker \& Jaeger, 1987), xylan and cellulose (Ten et al., 2004) were performed and were evaluated after 10 days. Growth at different temperatures $\left(4,15,20,25,30,37\right.$ and $\left.42{ }^{\circ} \mathrm{C}\right)$ and $\mathrm{pH}$ ( $\mathrm{pH} 5.0-10.0$, in increments of $0.5 \mathrm{pH}$ units) was assessed after 5 days incubation. Salt tolerance was tested on R2A medium supplemented with $1-10 \%$ (w/v) $\mathrm{NaCl}$ after 5 days incubation. Growth on nutrient agar (NA), trypticase soy agar (TSA) and MacConkey agar was also evaluated at $30{ }^{\circ} \mathrm{C}$. Growth on NA, TSA, MacConkey agar, R3A agar (Reasoner \& Geldreich, 1985), triple-sugar-iron 
agar (TSIA), Mueller-Hinton agar (MHA), Luria-Bertani (LB) agar and diluted media, all of which were made nutritionally poor by diluting them with distilled water and solidifying them with $1.5 \%$ agarose, was also evaluated at $25{ }^{\circ} \mathrm{C}$. Sensitivity to antibiotics was tested on R2A plates, using antibiotic discs containing the following amounts ( $\mu \mathrm{g}$, unless indicated otherwise): streptomycin, 2, 5, 10 and 20; penicillin, 2, 5, 10 and $20 \mathrm{U}$; chloramphenicol, 5, 10, 30 and 50; ampicillin, 2, 5, 10 and 20; cephalothin, 2, 6, 10 and 20; gentamicin, 2, 5, 10 and 20; novobiocin, 10, 30, 50 and 100; tetracycline, 1, 3, 5 and 10; kanamycin, 5, 10, 30 and 50; lincomycin, 1, 2, 5 and 10; oleandomycin, 0.6, 1, 3 and 6; neomycin, 10, 20, 30 and 50; carbenicillin, 0.5, 1.5, 4 and 6; erythromycin, 5, 10, 15 and 30 .

Cells of strain Gsoil $085^{\mathrm{T}}$ were Gram-negative, rod-shaped, strictly aerobic, non-spore-forming and non-motile. Colonies grown on R2A agar plates for 3 days were circular, smooth, convex, glossy, orange-coloured and 2$4 \mathrm{~mm}$ in diameter. On R2A agar, strain Gsoil $085^{\mathrm{T}}$ was able to grow at $4-30{ }^{\circ} \mathrm{C}$ but not at $37^{\circ} \mathrm{C}$; the optimal growth temperature was $20-25{ }^{\circ} \mathrm{C}$. Physiological characteristics of strain Gsoil $085^{\mathrm{T}}$ are summarized in the species description and a comparison of selective characteristics with those of its nearest phylogenetic neighbour is given in Table 1.

To measure the $\mathrm{G}+\mathrm{C}$ content of the chromosomal DNA, genomic DNA of the novel strain was extracted and purified as described by Moore \& Dowhan (1995), enzymically degraded into nucleosides and then determined as described by Mesbah et al. (1989) using reversedphase HPLC. Cellular fatty acid profiles were determined for strains grown on R2A plates for 4 days. The cellular fatty acids were saponified, methylated and extracted according to the protocol of the Sherlock Microbial Identification System (MIDI). The fatty acids were analysed by gas chromatography (6890; Hewlett Packard) and identified with the Microbial Identification software package (Sasser, 1990).

The $\mathrm{G}+\mathrm{C}$ content of the genomic DNA of strain Gsoil $085^{\mathrm{T}}$ was $40.5 \mathrm{~mol} \%$. The following cellular fatty acids were present (at more than $1.0 \%$ ) in strain Gsoil $085^{\mathrm{T}}$ : $\mathrm{C}_{14: 0}(1.1 \%), \mathrm{C}_{15: 0}(2.0 \%), \mathrm{C}_{16: 0}(8.2 \%)$, iso- $\mathrm{C}_{15: 0}$ (13.9\%), iso- $\mathrm{C}_{15: 0} 3-\mathrm{OH}(3.7 \%)$, iso- $\mathrm{C}_{15: 1} \mathrm{G}(3.8 \%)$, iso- $\mathrm{C}_{17: 0} 3-\mathrm{OH}(3.4 \%)$, anteiso- $\mathrm{C}_{15: 0}(1.8 \%), \mathrm{C}_{16: 0} 3-\mathrm{OH}$ $(1.2 \%), \mathrm{C}_{16: 1} \omega 5 c(8.6 \%)$, summed feature $3\left(\mathrm{C}_{14: 0} 3-\mathrm{OH}\right.$ and/or iso- $\mathrm{C}_{16: 1} \mathrm{I}, 1.1 \%$ ), summed feature 4 (iso- $\mathrm{C}_{15: 0} 2$ $\mathrm{OH}$ and/or $\left.\mathrm{C}_{16: 1} \omega 7 c, 45.4 \%\right)$ and an unknown fatty acid (equivalent chain length of 13.566, 1.6\%). Some qualitative and quantitative differences in fatty acid content could be observed between strain Gsoil $085^{\mathrm{T}}$ and its phylogenetically closest relative, E. oligotrophica, perhaps because of differences in cultivation conditions (Table 2).

On the basis of the data and observations described above, strain Gsoil $085^{\mathrm{T}}$ should be assigned to the genus Emticicia as the type strain of a novel species, for which the name Emticicia ginsengisoli sp. nov. is proposed.
Table 2. Comparison of fatty acid compositions (\%) of strain Gsoil $085^{\top}$ and E. oligotrophica MTCC $6937^{\top}$

Data for E. oligotrophica MTCC6937 ${ }^{\mathrm{T}}$ were taken from Saha \& Chakrabarti (2006). -, Not detected.

\begin{tabular}{|c|c|c|}
\hline Fatty acid & Gsoil $085^{\mathrm{T}}$ & $\begin{array}{c}\text { E. oligotrophica } \\
{\text { MTCC } 6937^{\mathrm{T}}}^{\text {MT }}\end{array}$ \\
\hline $\mathrm{C}_{16: 0}$ & 8.2 & - \\
\hline iso- $\mathrm{C}_{15: 0}$ & 13.9 & 42.9 \\
\hline iso- $\mathrm{C}_{15: 0} 3-\mathrm{OH}$ & 3.7 & 5.6 \\
\hline iso- $\mathrm{C}_{17: 0} 3-\mathrm{OH}$ & 3.4 & 12.5 \\
\hline anteiso- $\mathrm{C}_{15: 0}$ & 1.8 & 12.2 \\
\hline $\mathrm{C}_{15: 1} \omega 6 c$ & - & 5.5 \\
\hline $\mathrm{C}_{16: 1} \omega 5 c$ & 8.6 & 3.8 \\
\hline Summed feature $4^{*}$ & 45.4 & 11.3 \\
\hline
\end{tabular}

* Summed features represent groups of two or three fatty acids that could not be separated by GLC with the MIDI system. Summed feature 4 contained iso- $\mathrm{C}_{15: 0} 2-\mathrm{OH}$ and/or $\mathrm{C}_{16: 1} \omega 7 c$.

\section{Description of Emticicia ginsengisoli sp. nov.}

Emticicia ginsengisoli (gin.seng.i.so'li. N.L. n. ginsengum ginseng; L. n. solum soil; N.L. gen. n. ginsengisoli of soil from a ginseng field, the source of the type strain).

Cells are Gram-negative, strictly aerobic, non-spore-forming, non-motile, rod-shaped, $0.3-0.4 \mu \mathrm{m}$ in diameter and 3-5 $\mu \mathrm{m}$ in length. Grows at temperatures between 4 and $30{ }^{\circ} \mathrm{C}$, with optimum growth at $20-25{ }^{\circ} \mathrm{C}$. The $\mathrm{pH}$ growth range is between $\mathrm{pH} 5.0$ and 8.5, with an optimum between $\mathrm{pH} 6.5$ and 7. Growth occurs in the absence of $\mathrm{NaCl}$ and in the presence of $1.0 \%(\mathrm{w} / \mathrm{v}) \mathrm{NaCl}$, but not with $2.0 \%(\mathrm{w} / \mathrm{v}) \mathrm{NaCl}$. No growth occurs on LB agar, MacConkey agar or TSIA, but can occur on R2A, NA, TSA, MHA, R3A, 1/100 LB agar, 1/100 NA, 1/100 MacConkey agar, 1/100 TSA, 1/100 TSIA, 1/10 MHA and 1/100 MHA. Oxidase- and catalase-positive and reduces nitrate and nitrite under aerobic conditions. Negative for hydrolysis of DNA, casein, collagen, chitin, starch, CMcellulose, xylan and aesculin. The following substrates are utilized for growth: L-xylose, D-lactose, maltose, melibiose, sucrose, trehalose, raffinose and inulin. The following substrates are not utilized for growth: D-arabinose, Larabinose, D-glucose, D-galactose, D-mannose, D-fructose, D-xylose, D-fucose, ethanol, L-rhamnose, L-sorbose, Dlyxose, D-ribose, cellobiose, pyruvate, formate, acetate, propionate, 3-hydroxybutyrate, valerate, capric acid, malate, fumarate, phenylacetate, benzoate, 3-hydroxybenzoate, 4-hydroxybenzoate, citrate, lactate, malate, malonate, succinate, glutarate, tartrate, itaconate, adipate, suberate, oxalate, gluconate, dulcitol, inositol, D-adonitol, D-mannitol, D-sorbitol, xylitol, methanol, glycerol, salicin, amygdalin, glycogen, $\mathrm{N}$-acetyl-D-glucosamine, dextran, L-alanine, L-arginine, L-asparagine, L-aspartic acid, L-cysteine, Lglutamic acid, L-glutamine, L-histidine, glycine, L-isoleucine, L-leucine, L-lysine, L-methionine, L-phenylalanine, L-proline, 
L-serine, L-threonine, L-tryptophan, L-tyrosine and L-valine. In API 20E tests, positive results are obtained in the VogesProskauer test and for gelatinase activity, but negative results are obtained for arginine dihydrolase, lysine decarboxylase, ornithine decarboxylase, tryptophan deaminase, urease, hydrogen sulphide production and indole production. Acid is not produced from D-glucose, melibiose, amygdalin, L-arabinose, D-mannitol, inositol, D-sorbitol, L-rhamnose or sucrose. Susceptible to chloramphenicol $(30 \mu \mathrm{g})$, erythromycin $(15 \mu \mathrm{g})$, gentamicin $(20 \mu \mathrm{g})$, lincomycin $(5 \mu \mathrm{g})$, neomycin $(30 \mu \mathrm{g})$, novobiocin $(30 \mu \mathrm{g})$, penicillin G $(20 \mathrm{U})$, streptomycin $(5 \mu \mathrm{g})$ and tetracycline $(1 \mu \mathrm{g})$. The major fatty acids are iso- $\mathrm{C}_{15: 0} 2-\mathrm{OH}$ and/or $\mathrm{C}_{16: 1} \omega 7 c$, iso$\mathrm{C}_{15: 0} 3-\mathrm{OH}, \mathrm{C}_{16: 1} \omega 5 c$ and $\mathrm{C}_{16: 0}$. The $\mathrm{G}+\mathrm{C}$ content of genomic DNA of the type strain is $40.5 \mathrm{~mol} \%$.

The type strain, Gsoil $085^{\mathrm{T}}\left(=\mathrm{KCTC} 12588^{\mathrm{T}}=\mathrm{LMG}\right.$ $23396^{\mathrm{T}}$ ), was isolated from soil from a ginseng field in Pocheon Province, South Korea.

\section{Acknowledgements}

This work was supported by the 21C Frontier Microbial Genomics and Application Center Program, Ministry of Science and Technology (grant MG05-0101-4-0), Republic of Korea.

\section{References}

Atlas, R. M. (1993). Handbook of Microbiological Media. Edited by L. C. Parks. Boca Raton, FL: CRC Press.

Bowman, J. P., Nichols, C. M. \& Gibson, J. A. E. (2003). Algoriphagus ratkowskyi gen. nov., sp. nov., Brumimicrobium glaciale gen. nov., sp. nov., Cryomorpha ignava gen. nov., sp. nov. and Crocinitomix catalasitica gen. nov., sp. nov., novel flavobacteria isolated from various polar habitats. Int J Syst Evol Microbiol 53, 1343-1355.

Brettar, I., Christen, R. \& Höfle, M. G. (2004). Aquiflexum balticum gen. nov., sp. nov., a novel marine bacterium of the CytophagaFlavobacterium-Bacteroides group isolated from surface water of the central Baltic Sea. Int J Syst Evol Microbiol 54, 2335-2341.

Buck, J. D. (1982). Nonstaining (KOH) method for determination of Gram reactions of marine bacteria. Appl Environ Microbiol 44, 992-993.

Cappuccino, J. G. \& Sherman, N. (2002). Microbiology: a Laboratory Manual, 6th edn. Menlo Park, CA: Benjamin/Cummings.

Felsenstein, J. (1985). Confidence limit on phylogenies: an approach using the bootstrap. Evolution 39, 783-791.

Glöckner, F. O., Fuchs, B. M. \& Amann, R. (1999). Bacterioplankton compositions of lakes and oceans: a first comparison based on fluorescence in situ hybridization. Appl Environ Microbiol 65, 3721-3726.

Hall, T. A. (1999). BioEdit: a user-friendly biological sequence alignment editor and analysis program for Windows 95/98/NT. Nucleic Acids Symp Ser 41, 95-98.

Höfle, M. G. (1982). Glucose uptake of Cytophaga johnsonae studied in batch and chemostat culture. Arch Microbiol 133, 289-294.

Im, W.-T., Jung, H.-M., Cui, Y.-S., Liu, Q.-M., Zhang, S.-L. \& Lee, S.-T. (2005). Cultivation of the three hundreds of bacterial species from soil of a ginseng field and mining the novel lineage bacteria. In Proceedings of the International Meeting of the Federation of Korean
Microbiological Societies, abstract A035, p. 169. Seoul: Federation of Korean Microbiological Societies.

Ivanova, E. P., Alexeeva, Y. V., Flavier, S., Wright, J. P., Zhukova, N. V., Gorshkova, N. M., Mikhailov, V. V., Nicolau, D. V. \& Christen, R. (2004). Formosa algae gen. nov., sp. nov., a novel member of the family Flavobacteriaceae. Int J Syst Evol Microbiol 54, 705-711.

Kim, M. K., Im, W.-T., Ohta, H., Lee, M. \& Lee, S.-T. (2005). Sphingopyxis granuli sp. nov., a $\beta$-glucosidase producing bacterium in the family Sphingomonadaceae in $\alpha-4$ subclass of the Proteobacteria. J Microbiol 43, 152-157.

Kimura, M. (1983). The Neutral Theory of Molecular Evolution. Cambridge: Cambridge University Press.

Kouker, G. \& Jaeger, K.-E. (1987). Specific and sensitive plate assay for bacterial lipases. Appl Environ Microbiol 53, 211-213.

Kumar, S., Tamura, K. \& Nei, M. (2004). MEGA3: integrated software for molecular evolutionary genetics analysis and sequence alignment. Brief Bioinform 5, 150-163.

Lau, K. W. K., Ng, C. Y. M., Ren, J., Lau, S. C. L., Qian, P.-Y., Wong, P.-K., Lau, T. C. \& Wu, M. (2005). Owenweeksia hongkongensis gen. nov., sp. nov., a novel marine bacterium of the phylum 'Bacteroidetes'. Int J Syst Evol Microbiol 55, 1051-1057.

Liu, Q.-M., Im, W.-T., Lee, M., Yang, D.-C. \& Lee, S.-T. (2006). Dyadobacter ginsengisoli sp. nov. isolated from soil of a ginseng field in South Korea. Int J Syst Evol Microbiol 56, 1939-1944.

Ludwig, W. \& Klenk, H.-P. (2001). Overview: a phylogenetic backbone and taxonomic framework for procaryotic systematics. In Bergey's Manual of Systematic Bacteriology, 2nd edn, vol. 1, pp. 49-65. Edited by D. R. Boone, R. W. Castenholz \& G. M. Garrity. New York: Springer.

Mesbah, M., Premachandran, U. \& Whitman, W. B. (1989). Precise measurement of the $\mathrm{G}+\mathrm{C}$ content of deoxyribonucleic acid by highperformance liquid chromatography. Int J Syst Bacteriol 39, 159-167.

Moore, D. D. \& Dowhan, D. (1995). Preparation and analysis of DNA. In Current Protocols in Molecular Biology, pp. 2-11. Edited by F. W. Ausubel, R. Brent, R. E. Kingston, D. D. Moore, J. G. Seidman, J. A. Smith \& K. Struhl. New York: Wiley.

Nedashkovskaya, O. I., Kim, S. B., Han, S. K., Rhee, M. S., Lysenko, A. M., Falsen, E., Frolova, G. M., Mikhailov, V. V. \& Bae, K. S. (2004). Ulvibacter litoralis gen. nov., sp. nov., a novel member of the family Flavobacteriaceae isolated from the green alga Ulva fenestrata. Int $J$ Syst Evol Microbiol 54, 119-123.

Nedashkovskaya, O. I., Kim, S. B., Lysenko, A. M., Frolova, G. M., Mikhailov, V. V., Lee, K. H. \& Bae, K. S. (2005). Description of Aquimarina muelleri gen. nov., sp. nov., and proposal of the reclassification of [Cytophaga] latercula Lewin 1969 as Stanierella latercula gen. nov., comb. nov. Int J Syst Evol Microbiol 55, 225-229.

Nikitin, D. I., Strömpl, C., Oranskaya, M. S. \& Abraham, W.-R. (2004). Phylogeny of the ring-forming bacterium Arcicella aquatica gen. nov., sp. nov. (ex Nikitin et al. 1994), from a freshwater neuston biofilm. Int J Syst Evol Microbiol 54, 681-684.

O’Sullivan, L. A., Rinna, J., Humphreys, G., Weightman, A. J. \& Fry, J. C. (2005). Fluviicola taffensis gen. nov., sp. nov., a novel freshwater bacterium of the family Cryomorphaceae in the phylum 'Bacteroidetes'. Int J Syst Evol Microbiol 55, 2189-2194.

O’Sullivan, L. A., Rinna, J., Humphreys, G., Weightman, A. J. \& Fry, J. C. (2006). Culturable phylogenetic diversity of the phylum 'Bacteroidetes' from river epilithon and coastal water and description of novel members of the family Flavobacteriaceae: Epilithonimonas tenax gen. nov., sp. nov. and Persicivirga xylanidelens gen. nov., sp. nov. Int J Syst Evol Microbiol 56, 169-180.

Pinhassi, J., Azam, F., Hemphälä, J., Long, R. A., Martinez, J., Zweifel, U. L. \& Hagström, ̊. (1999). Coupling between bacterioplankton 
species composition, population dynamics, and organic matter degradation. Aquat Microb Ecol 17, 13-26.

Reasoner, D. J. \& Geldreich, E. E. (1985). A new medium for the enumeration and subculture of bacteria from potable water. Appl Environ Microbiol 49, 1-7.

Reichenbach, H. (1989). The order Cytophagales Leadbetter 1974, $99^{\mathrm{AL}}$. In Bergey's Manual of Systematic Bacteriology, vol. 3, pp. 20112073. Edited by J. T. Staley, M. P. Bryant, N. Pfennig \& J. C. Holt. Baltimore: Williams \& Wilkins.

Rickard, A. H., Stead, A. T., O’May, G. A., Lindsay, S., Banner, M., Handley, P. S. \& Gilbert, P. (2005). Adhaeribacter aquaticus gen. nov., sp. nov., a Gram-negative isolate from a potable water biofilm. Int $J$ Syst Evol Microbiol 55, 821-829.

Saha, P. \& Chakrabarti, T. (2006). Emticicia oligotrophica gen. nov., sp. nov., a new member of the family 'Flexibacteraceae', phylum Bacteroidetes. Int J Syst Evol Microbiol 56, 991-995.

Saitou, N. \& Nei, M. (1987). The neighbor-joining method: a new method for reconstructing phylogenetic trees. Mol Biol Evol 4, 406-425.

Sasser, M. (1990). Identification of bacteria by gas chromatography of cellular fatty acids, MIDI Technical Note 101. Newark, DE: MIDI Inc.

Sohn, J. H., Lee, J.-H., Yi, H., Chun, J., Bae, K. S., Ahn, T.-Y. \& Kim, S.-J. (2004). Kordia algicida gen. nov., sp. nov., an algicidal bacterium isolated from red tide. Int J Syst Evol Microbiol 54, 675-680.

Stackebrandt, E. \& Goebel, B. M. (1994). Taxonomic note: a place for DNA-DNA reassociation and $16 \mathrm{~S}$ rRNA sequence analysis in the present species definition in bacteriology. Int $J$ Syst Bacteriol 44, 846-849.
Ten, L. N., Im, W.-T., Kim, M.-K., Kang, M.-S. \& Lee, S.-T. (2004). Development of a plate technique for screening of polysaccharidedegrading microorganisms by using a mixture of insoluble chromogenic substrates. J Microbiol Methods 56, 375-382.

Thompson, J. D., Gibson, T. J., Plewniak, F., Jeanmougin, F. \& Higgins, D. G. (1997). The CLUSTAL_X windows interface: flexible strategies for multiple sequence alignment aided by quality analysis tools. Nucleic Acids Res 25, 4876-4882.

Tschech, A. \& Pfennig, N. (1984). Growth yield increase linked to caffeate reduction in Acetobacterium woodii. Arch Microbiol 137, 163-167.

Van Trappen, S., Vandecandelaere, I., Mergaert, J. \& Swings, J. (2004). Gillisia limnaea gen. nov., sp. nov., a new member of the family Flavobacteriaceae isolated from a microbial mat in Lake Fryxell, Antarctica. Int J Syst Evol Microbiol 54, 445-448.

Widdel, F. \& Bak, F. (1992). Gram-negative mesophilic sulfatereducing bacteria. In The Prokaryotes, 2nd edn, pp. 3352-3378. Edited by A. Balows, H. G. Trüper, M. Dworkin, W. Harder \& K. H. Schleifer. New York: Springer.

Widdel, F., Kohring, G. \& Mayer, F. (1983). Studies in dissimilatory sulfate-reducing bacteria that decompose fatty acids. III. Characterization of the filamentous gliding Desulfonema limicola gen. nov. sp. nov., and Desulfonema magnum sp. nov. Arch Microbiol 134, 286-294.

Yi, H. \& Chun, J. (2004). Hongiella mannitolivorans gen. nov., sp. nov., Hongiella halophila sp. nov. and Hongiella ornithinivorans sp. nov., isolated from tidal flat sediment. Int J Syst Evol Microbiol 54, 157-162. 